\title{
下水污泥焼却灰からのリンとアルミニウムの資源回収
}

\author{
高 橋 泰 弘*
}

\section{Recovery of Phosphorus and Aluminum from Incinerator Ash of Sewage Sludge}

\author{
Yasuhiro TAKAHASHI* \\ * Iriezaki Sogo Sludge Center, Kawasaki City Hall, 3-24-12 Siohama, Kawasaki-ku, Kawasaki, Kanagawa 210-0826, \\ Japan
}

\begin{abstract}
To effectively use sewer system resources, experiments were carried out to recover phosphorus and aluminum from incinerator ash of sewage sludge. I found that, if an alkali solution is added to sewage ash, phosphorus and aluminum can be selectively eluted to the solution and separated by adding calcium hydroxide. Phosphorus and aluminum were recovered in the form of calcium phosphate and sodium aluminate respectively. The recovered phosphorus compound was $100 \%$ citric acid-soluble, and contained $36 \%$ phosphoric acid. With respect to toxic heavy metals specified by the Fertilizer Control Law, the $\mathrm{Cd}$ and $\mathrm{As}$ contents were below the specified standards, and $\mathrm{Ni}, \mathrm{Cr}, \mathrm{Pb}$ and $\mathrm{Hg}$ were not detected in the available chemical analyses. The recovered phosphate was of acceptable quality for use as fertilizer. The recovered aluminum solution contained $17000 \mathrm{mg} / 1 \mathrm{Al}$, and may be used as flocculant in the removal of phosphorus from sewage.
\end{abstract}

Key words: phosphorus, aluminum, incinerator ash of sewage sludge, alkali elution, phosphorus recovery

\section{1.はじめに}

近年，閉鎖性水域での富栄養化の元凶の一つであるリ ンを下水から除去する必要性が叫ばれて扔り，生物脱り ン法, 凝集剤添加活性污泥法など様々な研究が行われて いる。これら下水道の高度処理方法により，リンは除去 されるがそれらは，全て污泥に蓄積されることから，よ り一層, 污泥のリン濃度が増加する。また下水污泥焼却 灰（以下，焼却厕）は污泥を脱水し，焼却処理したもの であるため，リンはさらに䀼縮され，これは低品位のリ ン鉱石並みのリン含有率である。燒却灰は, 日久一定量 発生するため安定供給可能であり，下水道が有する有用 な資源の一つである。

リンは富栄養化を引き起こす元素であるが，資源とし ては人間の生活になくてはならないものであり，農業， 医薬の分野では広く用いられている。しかしながら日本 にはリンの原料であるリン鉱石は，ほとんどなく全量を 海外からの輸入に頼っている。そのリン鉱石も埋蔵量と 生産量の関係から経済的埋蔵量は2045年に枯渴し，その 後は採掘が困難となることが予測されている1。

これらのことから焼却灰からリンを回収することは， 効率的であり，かつ有限なりン資源の枯渴を防ぐ有効な 手段と考光，検討を重衫てきた。その過程において，焼 却灰をアルカリ溶液中で覺汼するとリンとアルミニウム
が選択的に溶出することを報告した ${ }^{2)}$ 。焼却灰から溶出 したリンを回収するにあたり第一に考慮したのは，資源 として再利用しやすい形態で回収することである。我が 国ではりンの原料であるリン鉱石を全畽，海外から輸入 し，その8割を肥料として利用している゙๋ここのためリン を肥料として回収すれば，リンの資源循環がスムーズに 行われると考免、リン酸カルシウムとして回収すること を試みた。そして，アルカリ溶出で得られたリンとアル ミニウムを含む溶液からアルミニウムを有機溶媒で抽出 することで，リンとアルミニウムを分離させ，リンはり ン酸カルシウムとして，アルミニウムは硫酸アルミニウ ムとして回収する方法を考案しだ2。しかし，工程が複雑 であり，有機溶媒などの試薬を使用することから排水処 理，薬品管理にコストがかかり，さらに多額の薬品コス 卜もかかることが予想された。そこで今度は，有機試薬 ではなく，無機試薬のみを使用してアルカリ溶出液から リンを沈殿させることでリンとアルミニウムを分離さ せリンは同じくリン酸カルシウムとして，アルミニウ ムはアルミン酸ナトリウム溶液として回取する検討を 行った。この方法により,より簡易な工程で, 有機試薬 を使用せず，薬品コストも以前の1/4 に削減可能とな り，より実用的なりン，アルミニウム回収方法について 知見が得られたので報告する。 
Table 1 Chemical composition of incinerator ash of sewage

\begin{tabular}{|c|c|c|c|c|c|c|c|c|c|c|c|c|c|c|}
\hline $\begin{array}{c}\text { Element } \\
\text { Incinerator Ash }\end{array}$ & $\begin{array}{c}P \\
65000\end{array}$ & $\begin{array}{c}\mathrm{Al} \\
68000\end{array}$ & $\begin{array}{c}S i \\
220000\end{array}$ & $\begin{array}{c}\mathrm{Fe} \\
62000\end{array}$ & $\begin{array}{c}\mathrm{Ca} \\
47000\end{array}$ & $\begin{array}{c}\mathrm{Zn} \\
2500\end{array}$ & $\begin{array}{c}\mathrm{Cu} \\
1200\end{array}$ & $\begin{array}{c}\mathrm{Mn} \\
1000\end{array}$ & $\begin{array}{c}\mathrm{Cr} \\
300\end{array}$ & $\begin{array}{c}\mathrm{Ni} \\
160\end{array}$ & $\begin{array}{l}\mathrm{Pb} \\
160\end{array}$ & $\begin{array}{l}\text { As } \\
34\end{array}$ & $\begin{array}{l}\mathrm{Cd} \\
4.1\end{array}$ & $\begin{array}{l}\mathrm{Se} \\
<2.5\end{array}$ \\
\hline
\end{tabular}

\section{2. 实験方法}

\section{1 試料および測定方法}

(1) 試料

実験に用いた焼却灰は，川崎市入江崎総合スラッジセ ンターで採取したものを使用した。当污泥処理施設では 市内 4 箇所の水処理センターで発生した下水污泥を集約 し，污泥に高分子凝集剂を加え，ベルトプレスにより脱 水し，流動焼却炬にて焼却処理している。

焼却灰の成分の一例を Table 1 に示す。Table 1 に示 したように，焼却灰にはケイ素に次いでアルミニウム， リンが多く含まれているが，その他に鈶，クロム，七素， カドミウムなど有害な金属も含まれていることが確認さ れた。

(2) 測定方法

全ての分析はJIS K 0102法にもとづいて行った。り ンの定量分析はモりブデン青吸光光度法により，島津製 作所社製可視紫外分光計UV-2200を用いて测定した。ま た，アルミニウム，カルシウム，その他重金属は，島津 製作所社製原子吸光分析計 $A A-6800$ 用いて測定した。

\section{2 リン回収实験}

Table 1 に示したように焼却死にはク口ムなど有害な 重金属が含まれているが，水酸化ナトリウムなどのアル カリ溶液中で覺汼することでリンとアルミニウムが選択 的に溶出することはすでに報告した2)。本諭では，アルカ リ溶出にて得られた溶液（以下，アルカリ溶出液）から リンとアルミニウムを分離・回取する方法について報告 する。

(1) 原理

アルカリ溶出液は高アルカリであることから，カルシ ウムを加えると下記の式(1)により，リンはリン酸カルシ ウム[ハイドロキシアパタイト $\left.(\mathrm{HAp}) \mathrm{Ca}_{5}(\mathrm{OH})\left(\mathrm{PO}_{4}\right)_{3}\right]$ となり，白色の沈殿を生じる。

$3 \mathrm{PO}_{4}{ }^{3-}+5 \mathrm{Ca}^{2+}+\mathrm{OH}^{-} \rightarrow \mathrm{Ca}_{5}(\mathrm{OH})\left(\mathrm{PO}_{4}\right)_{3}$

一方,アルミニウムはカルシウムとほとんど反応せず, アルミン酸ナトリウムとして溶液のまま存在することか ら，沈殿したりン陵カルシウムを回収することでリンと アルミニウムを分離することが可能と考えた。

(2) アルカリ溶出液

アルカリ溶出液 $(20 \mathrm{w} / \mathrm{v} \%$ ) は, 水に対して焼却灰を200 $\mathrm{g} \cdot \mathrm{l}^{-1}$, 水酸化ナトリウム濃度を $4 \%, 40^{\circ} \mathrm{C}$ で 1 時間鄮汼 させ，ろ過したものを使用した。同様にアルカリ溶出液 $(40 \mathrm{w} / \mathrm{v} \%)$ は，水に対して焼却灰を $400 \mathrm{~g} \cdot l^{-1}$ ，水酸化小 トリウム濃度を $8 \% ４ 0^{\circ} \mathrm{C}$ で 1 時間挸挥させ，ろ過した ものを使用した。主な分析結果を Table 2 に示す。

Table 2 Contents of alkali eluate

\begin{tabular}{cccccccc} 
& $\mathrm{pH}$ & $\mathrm{P}$ & $\mathrm{Al}$ & $\mathrm{Zn}$ & $\mathrm{Pb}$ & $\mathrm{As}$ & $\mathrm{Se}$ \\
$20 \mathrm{~W} / \mathrm{v} \%$ & 12.5 & 7300 & 5400 & $<2$ & $<2$ & 0.3 & 0.4 \\
$40 \mathrm{~W} / \mathrm{V}^{\mathrm{t} / \mathrm{s}}$ & 12.7 & 14000 & 6700 & $<2$ & $<2$ & 0.6 & 0.6 \\
\hline
\end{tabular}

\section{$2.2 .1 \mathrm{pH}$ とリン, アルミニウム回収率}

カルシウムを添加するとき，アルカリ溶出液の $\mathrm{pH}$ が リン，アルミニウムの回収率にどのような影響を与える かを調べるためにアルカリ溶出液を $\mathrm{pH}$ 末調整 (Run1) と $20 \%$ 水酸化ナトリウムで $\mathrm{pH} 13$ に調整（Run2）したと きの比較実験を行った。アルカり溶出液 $(20 \mathrm{w} / \mathrm{v} \%) 100$ $\mathrm{m} l$ にアルカリ溶液中のリンに対して理論量 (HAp を生 成するのに必要な量; $\mathrm{Ca} / \mathrm{P}$ の mol 比=1.67) の塩化力 ルシウム水溶液 $(4.4 \mathrm{~g} /$ 水 $30 \mathrm{~m} l)$ を添加し 1 時間擤抖し遠 心分離後，乃過した。

\section{2 .2 水酸化カルシウムによるリン回収}

先の実験ではカルシウム源として塩化カルシウムを使 用したが，ここでは水酸化カルシウムによるリン回収を 試みた。水酸化カルシウムは水に溶けにくいことからア ルカリ溶出液中のリンとの反応性は塩化カルシウムより 低いと考えたため，添加するカルシウムはアルカリ溶液 中のリンに対して理論量の1.2倍とし，摫拌㭙間は同じく 1 時間とした（Run3）。実験は2.2.1と同じスケールで 行った。比較のために $\mathrm{pH} 13$ に調整した後,カルシウム量 を理論值の1.2倍にした塩化カルシウム水溶液を添加し た実験（Run4）も行った。

\section{2 .3 最適な水酸化カルシウム添加量}

先の実験2.2.2では水酸化カルシウム量を理論量の1.2 倍として実験を行ったが，カルシウム添加量の増大がリ ン回収率，アルミニウム損失率，リン酸カルシウムのリ ンアルミニウム含有率にどのように影響するかを調心゙ るために実験を行った。水酸化カルシウム添加量は理諭 量の1.2倍 (Run5)，1.5倍 (Run6)，2 倍 (Run7) とし, 攪抖時間は同じく 1 時間とした。

\section{2 .4 攪挥時間}

リンと水酸化カルシウムとの反応に必要な時間を調心゙ るために攪抖時間とリン湢度の関係を調查し，アルミ二 ウムについても同様に調查した。またアルカリ溶出液の リン濃度によって最適反応時間が異なるかを調査するた めに焼却灰濃度 $20 \mathrm{w} / \mathrm{v} \%$ \%アルカリ溶出液と $40 \mathrm{w} / \mathrm{v} \%$ の アルカリ溶出液，2 種類において実験を行った (Run8, 9)。実験条件はアルカリ溶出液 $100 \mathrm{~m} l$ に理論量の1.2倍 の水酸化カルシウム安加え， 1〜16時間攪抖し，リン酸 カルシウムろ過後のろ液のリン, アルミニウム濃度を測 定した。

\section{2 .5 水酸化カルシウム添加方法の検討}

リンと水酸化カルシウムとの反応時間を短縮させる目 的で水酸化カルシウムの添加方法を粉末から水に㲘濁さ せる方法に変更して実験 (Run10)を行った。焼却灰濃度 $40 \mathrm{w} / \mathrm{v} \%$ のアルカリ溶出液 $100 \mathrm{~m} l$ にリンに対して理論量 の1.2倍の水酸化カルシウムを水に賏濁 $(6.7 \mathrm{~g} /$ 水 $20 \mathrm{~m} l)$ させ添加後 $1 \sim 5$ 時間攪挥させ溶液中のリン，アルミニ ウム濃度を測定した。以上の実験について Table 3 にま とめた。

2.2.6 アルカリ溶出時に使用する水酸化ナトリウム 量の削減 
Table 3 Precipitation condition

\begin{tabular}{|c|c|c|c|c|c|}
\hline Run No. & Adjustment of $\mathrm{pH}$ & Concentration of ash $\left(w / \mathrm{v}^{\circ}\right)$ & Reagent of $\mathrm{Ca}$ & Amount of $\mathrm{Ca}$ & Reaction time(h) \\
\hline 1 & - & 20 & $\mathrm{CaCl}_{2}$ & $\times 1$ & 1 \\
\hline 2 & 13 & 20 & $\mathrm{CaCl}_{2}$ & $\times 1$ & 1 \\
\hline 3 & - & 20 & $\mathrm{Ca}(\mathrm{OH})_{2}$ & $\times 1.2$ & 1 \\
\hline 4 & 13 & 20 & $\mathrm{CaCl}_{2}$ & $\times 1.2$ & 1 \\
\hline 5 & - & 20 & $\mathrm{Ca}(\mathrm{OH})_{2}$ & $\times 1.2$ & 1 \\
\hline 6 & - & 20 & $\mathrm{Ca}(\mathrm{OH})_{2}$ & $\times 1.5$ & 1 \\
\hline 7 & - & 20 & $\mathrm{Ca}(\mathrm{OH})_{2}$ & $\times 2$ & 1 \\
\hline 8 & - & 20 & $\mathrm{Ca}(\mathrm{OH})_{2}$ & $\times 1.2$ & $1 \sim 16$ \\
\hline 9 & - & 40 & $\mathrm{Ca}(\mathrm{OH})_{2}$ & $\times 1.2$ & $1 \sim 16$ \\
\hline 10 & - & 40 & $\mathrm{Ca}(\mathrm{OH})_{2 \text { exsparsion }}$ & $\times 1.2$ & $1 \sim 5$ \\
\hline
\end{tabular}

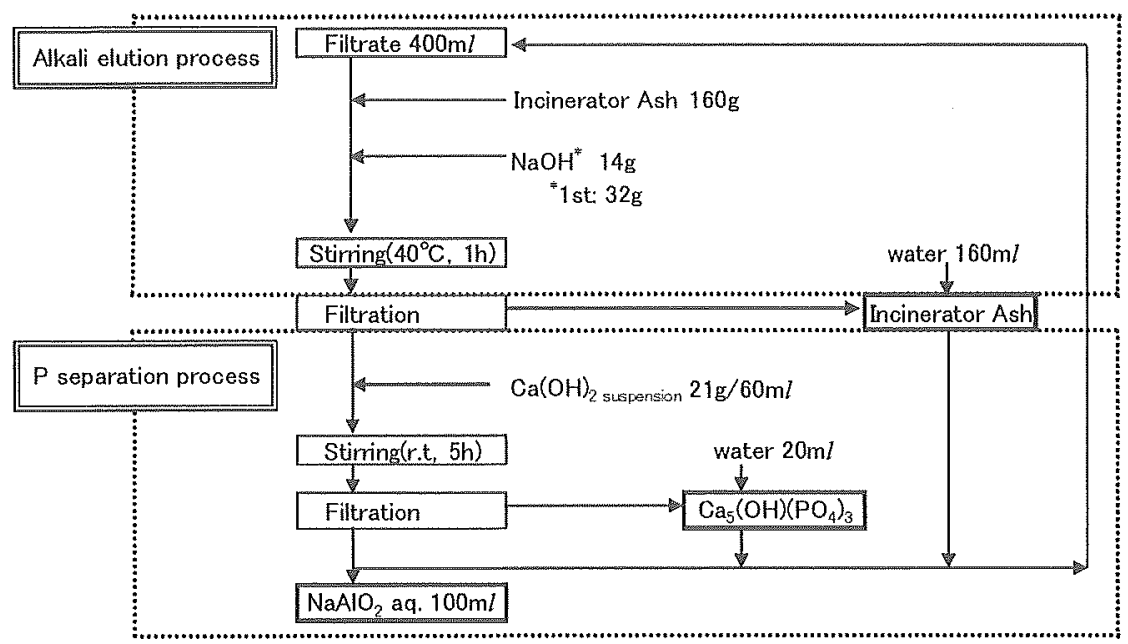

Fig. 1 Flow of continual recovery of $\mathrm{P}, \mathrm{Al}$

アルカリ溶出液に水酸化カルシウムを加えてリンを回 収すると下式(2)の反応により，アルカリ溶出の際に消費 した水酸化ナトリウムの一部が再生される。

$$
\begin{aligned}
3 \mathrm{Na}_{3} \mathrm{PO}_{4}+5 \mathrm{Ca}(\mathrm{OH})_{2} & \\
& \rightarrow \mathrm{Ca}_{5}(\mathrm{OH})\left(\mathrm{PO}_{4}\right)_{3}+9 \mathrm{NaOH}
\end{aligned}
$$

このことからリン回収後のろ液を再びアルカリ溶出液と して使用することにより，新たに溶出時に添加する水酸 化ナトリウム量を削減する実験を行った。

Fig. 1 に示した連続実験を想定して，実験は焼却灰濃 度 $40 \mathrm{w} / \mathrm{v} \%$ のアルカリ溶出液からリン回収後のろ液（り ン濃度 $\left.50 \mathrm{mg} \cdot \mathrm{l}^{-1}\right)$ とアルカリ溶出後の焼却灰を灰と同量 の水で洗い流した洗浄水 (リン濃度6,800 $\mathrm{mg} \cdot \mathrm{l}^{-1}$ ) とを合 わせた溶液 (リン裖度 $2,600 \mathrm{mg} \cdot l^{-1}$ ) のうち $100 \mathrm{~m} l$ 使用 して行った。燒却灰を濃度 $40 \mathrm{w} / \mathrm{v} \%$ になるように加え, 新 たに水酸化ナトリウム2.5〜 4.5\%量を添加し通常通り $40^{\circ} \mathrm{C}, 1$ 時間攪找し溶出を行った。

\subsection{7 連続回収実験}

実験2.2.6より,リン回収後のろ液をアルカリ溶出時に 使用することによって水酸化ナトリウムの消費量を削減 できることから，Fig.1に示すフローに従い連続実験を 行った。一つ目の工程はアル力り溶出であり，最初は水 $400 \mathrm{~m} l$ に焼却灰を $160 \mathrm{~g}$ ，水酸化十トリウム $32 \mathrm{~g}$ 加え，ア ルカリ溶出を行った。2 回目以降は水酸化ナトリウムを 約 $60 \%$ 削減し $14 \mathrm{~g}$ で実験を行った。リン酸カルシウム回 収後のろ液はアルミン酸ナトリウム溶液として一部回収 し，残り全ては次のアルカリ溶出に使用した。アルカリ 溶出後の死は灰と同量の水で洗浄し，同様にリン酸力ル シウムも水で洗浄し，洗浄液はどちらもりン酸カルシウ ムろ液（アルミン酸ナトリウム水溶液）に加之た。

\section{3.結果および考察}

$3.1 \mathrm{pH}$ とリン, アルミニウム回収率について $\mathrm{pH}$ を調整せずに塩化カルシウムを添加した時と $\mathrm{pH}$ を13に調整した後に塩化カルシウムを添加した結果を Table 4 に示した。

アルカリ溶出液の $\mathrm{pH}$ は12.5であったが添加した塩化 カルシウム水溶液の $\mathrm{pH}$ が9.4であったことから $\mathrm{pH}$ 末 調整の時はカルシウム添加後のろ液の pH は 11.6 となっ た。生成したりン酸カルシウムは沈降性が悪く，2 時間 放置してもほとんど分離せず，そのため遠心分離後，万 過することによってリン酸カルシウムを回収した。ろ過 に要した時間は 3 時間以上であり，回収物は多くの水を 含んでいた。それに対して pH を13に調整した実験では リン酸カルシウムの沈降性は若干良くなり，2 時間後に は固液界面が確認できたが，ろ過には多大な時間を必要 とした。

Table 4 より，pH を調整しないとリンは活100\%回 取できたがアルミニウムも約65\%が沈殿してしまった。 $\mathrm{pH}$ を 13 と高アルカリ条件下で塩化カルシウム水溶液を 添加するとリンの回収率は約 $89 \%$ となり，pH 未調整の 時と比べると若干悪化するがリン酸カルシウム回収後の ろ液には多くのアルミニウムが含まれていた（Al 損失率 $8.9 \%) 。 \mathrm{pH}$ を13にすることでカルシウムとアルミニウ ム (アルミン酸) との下式(3)の副反応を抑えることによ りリンのみがカルシウムと反応したと考えられる。

$$
\mathrm{Ca}^{2+}+2 \mathrm{AlO}_{2}^{-\rightarrow} \mathrm{Ca}\left(\mathrm{AlO}_{2}\right)_{2}
$$

以上の結果方ら，アルカリ溶出液（リン，アルミニウ ム混合液）からそれぞれを效率よく分離回収するには 
Table 4 Relation between $\mathrm{pH}$ of alkali eluate and $\mathrm{P}, \mathrm{AI}$ recovery

\begin{tabular}{|c|c|c|c|c|c|c|}
\hline & \multirow[b]{2}{*}{$\mathrm{pH}$} & \multirow[b]{2}{*}{ Filtrate $(\mathrm{m} l)$} & \multicolumn{2}{|l|}{$\mathbf{P}$} & \multicolumn{2}{|l|}{$\mathrm{Al}$} \\
\hline & & & Concentration $\left(m g=l^{-1}\right)$ & Recovery(\%) & Concentration $\left(\mathrm{mg}=\mathrm{l}^{-1}\right)$ & Al loss $(\%)$ \\
\hline Alkali elution & 12.5 & - & 7300 & - & 5400 & - \\
\hline $\mathrm{CaOl}_{2}$ & 11.6 & 85 & 15 & $99.8 \%$ & 2200 & $65 \%$ \\
\hline $\mathrm{pH} 13 \mathrm{CaCl}_{2}$ & 13.2 & 123 & 670 & $88.7 \%$ & 4000 & 9\% \\
\hline
\end{tabular}

Table 5 Comparison between $\mathrm{Ca}(\mathrm{OH})_{2}$ and $\mathrm{CaCl}_{2}$

\begin{tabular}{|c|c|c|c|c|c|c|}
\hline & \multirow[b]{2}{*}{$\mathrm{pH}$} & \multirow[b]{2}{*}{ Filtrate $(\mathrm{m} l)$} & \multicolumn{2}{|l|}{$P$} & \multicolumn{2}{|l|}{ Al } \\
\hline & & & Concentration $\left(\mathrm{mg}=l^{-1}\right)$ & Recovery(\%) & Concentration $\left(\mathrm{mg}^{\prime} l^{-1}\right)$ & Alloss $(\%)$ \\
\hline Alukali elution & 12.5 & - & 7300 & - & 5400 & - \\
\hline $\mathrm{Ca}(\mathrm{OH})_{2} \times 1.2$ & 13.5 & 93 & 350 & $95.5 \%$ & 5000 & $14 \%$ \\
\hline $\mathrm{pH} 13 \mathrm{CaCl}_{2} \times 1.2$ & 13.2 & 118 & 1 & $100 \%$ & 2600 & $43 \%$ \\
\hline
\end{tabular}

$\mathrm{pH}$ 未調整よりも高アルカリ側（pH13）に調整した方が 良いことがわかった。

\section{2 水酸化カルシウムによるリン回収}

実験2.2.1より,アルミニウムを沈殿させずにリンを選 択的に沈殿させるにはアルカリを加え $\mathrm{pH}$ を13に調整し てからカルシウムを加えなければならないことがわかっ た。そこでカルシウム源を塩化力ルシウムから水悪化力 ルシウムに変更することにより，アルカリ溶出液の $\mathrm{pH}$ 調整とカルシウム供給を一つの試薬でまかなうことが可 能であると考えた。水酸化カルシウムは塩化カルシウム に比べて安価な試薬であり，かつ $\mathrm{pH}$ 調整に必要な試薬 が必要ないことからコスト削隇につながると考え先験を 行った。

$\mathrm{pH}$ を調整せずに水酸化カルシウムを添加した結果と $\mathrm{pH}$ を13に調整した後に塩化カルシウムを添加した結果 をTable 5 に示した。

水酸化カルシウムを添加して得られたリン酸カルシウ ムは塩化力ルシウムの時と比較して，沈降性が良好であ りろ過時間も5 分程度と大幅に改善された。塩化力ルシ ウム水溶液存使用すると塩化力ルシウム水溶液中の塩化 カルシウムは全て解離しているため多量に存在するカル シウムイオンとアルカリ溶出液中のリン酸イオンが一度 に反応し，微紐な粒子のリン酸カルシウムが生成してし まうため，沈降性，ろ過性ともに悪い結果となったと考 えられる。それに対して水酸化力ルシウムを添加したと きは，水酸化力ルシウムは水への溶解度が低く，水に微 量しか溶解しないことから少しずつ式(4)の反応が起こ り，次に式(5)の反応が起こるため，一度に微細な粒子の リン酸カルシウムが生成されず徐々にりン敬カルシウム が生成し，それがリン酸カルシウムまたは未反応の水酸 化カルシウム表面上に付着し，粒子が成長していくため 沈降性，ろ過性の良好なりン酸カルシウムが生成された と考えられる。

$$
\begin{aligned}
& \mathrm{Ca}(\mathrm{OH})_{2} \rightarrow \mathrm{Ca}^{2+}+2 \mathrm{OH}^{-} \\
& 5 \mathrm{Ca}^{2+}+3 \mathrm{PO}_{4}{ }^{3+}+\mathrm{OH}^{-} \rightarrow \mathrm{Ca}_{5}(\mathrm{OH})\left(\mathrm{PO}_{4}\right)_{3}
\end{aligned}
$$

添加するカルシウム量を理論值の1倍加ら1.2倍に増 加したためリン回収率は約 $96 \%$ と良好であった。また水 酸化力ルシウムは穏やかに少しずつ反応することら， カルシウム量が過剩であるにもかか子らず，カルシウム とアルミニウム（アルミン酸）との副反応を抑えること ができ，カルシウムは選択的にリンと反応したと考えら 机る。

比較のために行った $\mathrm{pH} 13$ に調整した後に塩化カルシ

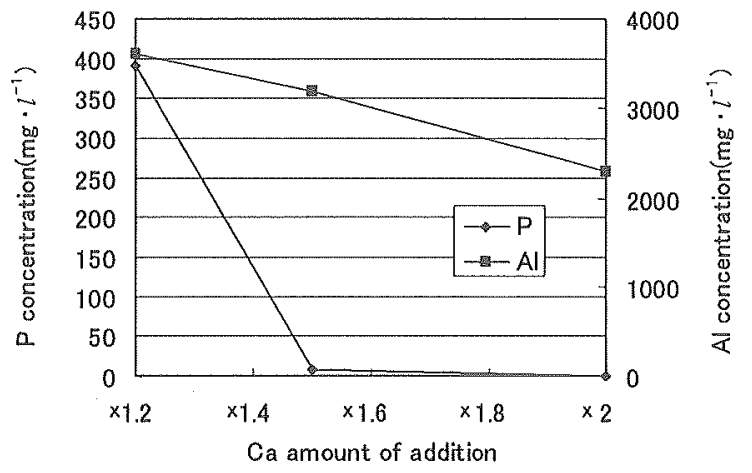

Fig. 2 Relation between $\mathrm{P}, \mathrm{Al}$ concentration and $\mathrm{Ca}$ amount of addition

Table 6 Contents of $\mathrm{P}, \mathrm{Al}$ in the precipitate

\begin{tabular}{cccc}
\hline & yield(g) & $\mathrm{P}(\%)$ & $\mathrm{Al}(\%)$ \\
\hline$\times 1.2$ & 3.6 & 12.2 & 0.8 \\
$\times 1.5$ & 4.1 & 11.5 & 1.1 \\
$\times 2$ & 5.2 & 8.5 & 2.3 \\
\hline
\end{tabular}

ウム水溶液を添加した実験では, 添加するカルシウム量 を理論值の 1 倍から 1.2 倍に増加したためリン回収率は ほほ100\%と良好な結果が得られたが, 過剩に添加したカ ルシウムがアルミニウムと反応してしまい $43 \%$ のアルミ ニウムが沈殿してしまった。以上のことから塩化カルシ ウムでは $\mathrm{pH}$ を13に調整してもカルシウムが過剩に存在 するとアルミニウムと反応してしまい，しかも生成した リン酸カルシウムは水分を多く含んで扔り，万過性も悪 いことがわかった。

\section{3 最適な水酸化カルシウム添加量について}

リン酸カルシウムろ過後のろ液のリン，アルミニウム 濃度とカルシウム添加署の関係を $\mathbf{F i g}$. 2 に示す。

水酸化カルシウムを過剩に加えれば加えるほど，リン の回収は良好となるがアルミニウムもともに沈殿を生 じ，濃度は低下していく結果となった。カルシウムは主 としてリンと反応し，過剰分がアルミニウムと反応した と考えられる。

次に得られた沈殿物の主な含有成分を Table 6 に示 के

Table 6 より,カルシウム添加量が多いほど, 未反応の 水酸化力ルシウムが多く存在することからりン酸カルシ ウムのリン含有率が低下した。また過剩に加えたカルシ ウムはアルミニウムと反応したためアルミニウム含有率 


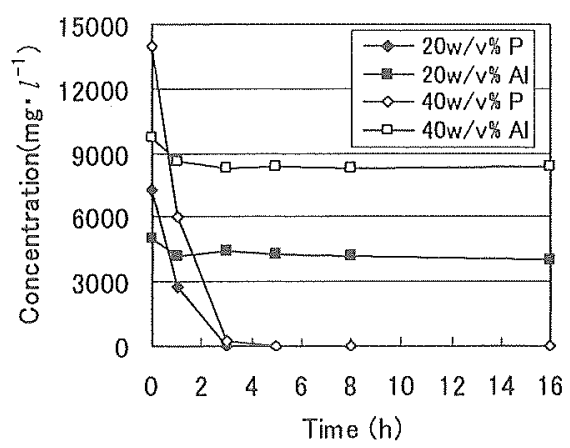

Fig. 3 Relation between $\mathrm{P}, \mathrm{Al}$ concentration and stirring time

は増加する結果となった。

回収したリン酸カルシウムはリン酸肥料，リン鉱石代 替品などとして利用されることを考慮した場合，回収物 中のリン含有率は高く，不純物が少ない方が再利用しや すいと考えられることおよび，試集コストを考慮すると できる限りカルシウム添加量は少ない方が良い。そのた め, 最適な水酸化カルシウム添加量は理論量の1.2倍とし た。次に反応時間を延長することでリン回収率を向上さ せ，同時にリン回収物のリン含有率を向上させることを 試みた。

\section{4 攪挥時間について}

アルカリ溶出液に水酸化カルシウムを添加した後のリ ン，アルミニウム賑度と攪汼時間の関係を Fig. 3 に示 के。

リン濃度は焼却夷濃度 $40 \mathrm{w} / \mathrm{v} \%$ のアルカリ溶出液が 20 $\mathrm{w} / \mathrm{v} \%$ に比べて 2 倍高いが，どちらもカルシウムと急激 に反応し，1時間で約 $50 \% ， 3$ 時間後には約 $98 \%$ が沈殿 し，攪拌を 5 時間行うとともにリン回収率はほほ $100 \%$ と なった。回収率では違いが確認できなかったが，5時間 後のリン濃度は焼却夾濃度 $40 \mathrm{w} / \mathrm{v} \%$ は $37 \mathrm{mg} \cdot l^{-1}, 20 \mathrm{w} /$ $\mathrm{v} \%$ は $1 \mathrm{mg} \cdot \mathrm{l}^{-1}$ と差が確認できた。この理由としてナト リウム濃度の違いが考えられる。焼却灰濃度 $40 \mathrm{w} / \mathrm{v} \%$ は $20 \mathrm{w} / \mathrm{v} \%$ と比べてアルカリ溶出時に使用する水酸化ナト リウム量も 2 倍であることからナトリウム濃度も2 倍高 い。ナトリウムイオンはリン酸カルシウムの生成抑制作

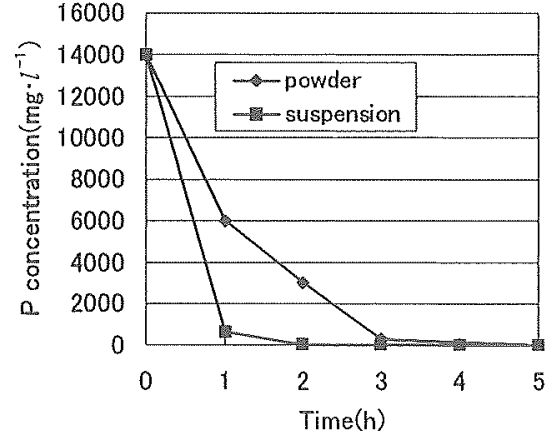

Fig. 4 Comparison of suspension and powder of calcium hydroxide

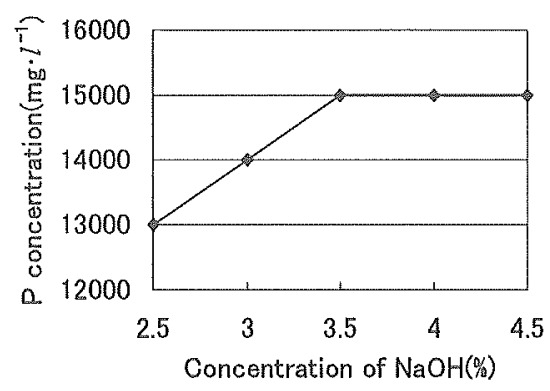

Fig. 5 Relation between $\mathrm{P}$ concentration and $\mathrm{NaOH}$ amount of addition in the re-elution

用を示す4てとからこれが要因の一つであると考えられ る。生成したりン酸カルシウムの性状は，ともに違いは 見られず，脱水性，沈降性ともに良好であった。

アルミニウム4どちらも水酸化カルシウム添加直後に 反応し，1割程度が沈殿するが 1 時間以降はほとんど反 応せずアルミニウムは約 $85 \%$ が残存する結果となった。

以上のことから，アルカリ溶出液からリンを回収する 際に，カルシウム添加前のリン濃度には関係なく，5時 間靦汼を行えばほぼ100\%リンが回収できることがわ 加った。

\section{5 水酸化カルシウム添加方法の検討}

実駼2.2.5上り，リンをほほ 間が 5 時間必要であることがわかった。しかし添加する 水酸化カルシウム文粉末状から水に奬濁させることに

Table 7 Result of continual recovery of $\mathrm{P}, \mathrm{Al}$

\begin{tabular}{|c|c|c|c|c|c|c|c|c|}
\hline & \multirow[b]{2}{*}{$\begin{array}{l}\text { Filtrate } \\
(\mathrm{ml})\end{array}$} & \multirow[b]{2}{*}{$\mathrm{pH}$} & \multicolumn{3}{|c|}{$\mathrm{P}$} & \multicolumn{3}{|c|}{$\mathrm{Al}$} \\
\hline & & & $\begin{array}{c}\text { Concentration } \\
\left(\mathrm{mg} \cdot l^{-1}\right)\end{array}$ & $\begin{array}{c}\text { Amount } \\
(\mathrm{mg})\end{array}$ & $\begin{array}{c}\text { Recover } \\
(\%)\end{array}$ & $\begin{array}{l}\text { Concentration } \\
\left(\mathrm{mg} \cdot l^{-1}\right)\end{array}$ & $\begin{array}{c}\text { Amount } \\
(\mathrm{mg})\end{array}$ & $\begin{array}{c}\text { Recovery } \\
\text { (\%) }\end{array}$ \\
\hline 1st Eluate & 310 & 14.0 & 12000 & 3700 & & 7600 & 2400 & \\
\hline 1st Filtrate & 345 & 14.4 & 58 & 20 & $99 \%$ & 5200 & 1800 & $75 \%$ \\
\hline 2nd Eluate & 310 & 13.3 & 15000 & 4700 & & 12000 & 3700 & \\
\hline 2nd Filtrate & 335 & 14.5 & 110 & 37 & $99 \%$ & 8800 & 2900 & $78 \%$ \\
\hline 3rd Eluate & 310 & 13.0 & 15000 & 4700 & & 15000 & 4700 & \\
\hline 3rd Filtrate & 330 & 14.4 & 300 & 99 & $98 \%$ & 11000 & 3600 & $77 \%$ \\
\hline 4th Eluate & 307 & 12.9 & 15000 & 4600 & & 16000 & 4900 & \\
\hline 4th Filtrate & 335 & 14.3 & 270 & 90 & $98 \%$ & 13000 & 4400 & $90 \%$ \\
\hline 5th Eluate & 320 & 13.0 & 15000 & 4800 & & 18000 & 5800 & \\
\hline 5th Filtrate & 350 & 14.4 & 330 & 120 & $98 \%$ & 15000 & 5300 & $91 \%$ \\
\hline 6th Eluate & 315 & 12.9 & 14000 & 4400 & & 20000 & 6300 & \\
\hline 6th Filtrate & 344 & 14.3 & 400 & 140 & $97 \%$ & 16000 & 5500 & $87 \%$ \\
\hline 7th Eluate & 315 & 13.0 & 14000 & 4400 & & 21000 & 6600 & \\
\hline 7th Filtrate & 343 & 14.4 & 370 & 130 & $97 \%$ & 17000 & 5800 & $88 \%$ \\
\hline 8th Eluate & 314 & 13.1 & 14000 & 4400 & & 21000 & 6600 & \\
\hline 8th Filtrate & 340 & 14.1 & 400 & 140 & $97 \%$ & 17000 & 5800 & $88 \%$ \\
\hline 9th Eluate & 312 & 13.1 & 14000 & 4400 & & 22000 & 6900 & \\
\hline gth Filtrate & 340 & 14.5 & 430 & 150 & $97 \%$ & 17000 & 5800 & $84 \%$ \\
\hline 10th Eluate & 310 & 13.3 & 15000 & 4700 & & 22000 & 6800 & \\
\hline 10th Filtrate & 338 & 14.5 & 360 & 120 & $97 \%$ & 18000 & 6100 & $90 \%$ \\
\hline
\end{tabular}


Table 8 Contents of calcium phosphate

\begin{tabular}{|c|c|c|c|c|c|c|c|c|}
\hline & yield $(g)$ & $\mathrm{P}$ & $\mathrm{Ca}$ & $\mathrm{Al}$ & $\mathrm{Fe}$ & $\mathrm{Zn}$ & As & Se \\
\hline Average of $6 t^{t h-10 t h ~}$ & 34.0 & 120000 & 290000 & 28000 & 55 & 6 & 3 & 3 \\
\hline
\end{tabular}

よって，アルカリ溶出液中でカルシウムを均一に分散さ せ，リンとの反応を促進させることによって必要な覺抖 時間が短縮できると考えた。水酸化カルシウムを粉末の まま添加した結果と惩濁させてから添加した結果を Fig. 4 に示した。

Fig. 4 より，水酸化力ルシウムは粉末で添加するよ り，愳濁させてから添加した方がリンとの反応は進みや すいことが確認できた。5 時間後のリン濃度を比較する と粉末添加では $37 \mathrm{mg} \cdot l^{-1}$ であったのに対して䀣濁添加

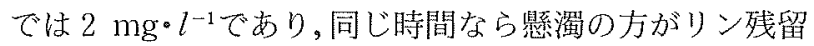
濃度は低い結果となった。このことから以後は全て水酸 化力ルシウムを奬濁させて添加した。

\section{6 アルカリ溶出時に使用する水酸化ナトリウム量 の削減}

再溶出時に添加した水酸化ナトリウム量とリン溶出結 果をFig. 5 に示す。

Fig.5より，再溶出時には3.5\%量の水酸化ナトリウ ムを加えれば，アルカリで溶出するリンをほぼ溶出する ことができることが確認できた。このことからリン回収 後のろ液を再利用することでアルカリ溶出時に使用する 水酸化ナトリウム量の約 $60 \%$ を削減することが可能と なった。

\section{7 連続実験について}

10回の連続実験結果を Table 7 に示す。リン酸カルシ ウム回収後のろ液を次のアルカリ溶出に連続使用するこ とによって，水酸化ナトリウム使用量を60\%削隇しても 焼却灭からのリン，アルミニウムの溶出濃度は低下しな かった。連続実験を行うことによってアルミニウムの回 収物（アルミン酸ナトリウム水溶液）濃度は徐々に高ま り, 定常状態を示した 6 回目以降は，アルミニウム濃度 が17,000mg/lでの安定した回収ができた。6回目以降 のリンの平均回収率は97\%であり, 回収したりン酸カル シウムの分析結果を Table 8 に示す。

リン回収物はリンとして $12 \%$ ，リン酸に換算すると 36\%含んでおり，高含有率であった。その他にカルシウ ムが29\%と多く、不純物であるアルミニウムは $2.8 \%$ 含ま 扎ていた。

\section{8 リン回収物について}

回収したリン酸カルシウムはリン酸として $36 \%$ 含んで おり，これは肥料として高含有率の部類に入る。しかも， 全てのりンがクエン酸溶性であることから肥料効果は高 いと考えられる。回収したリン酸カルシウムは水に溶け にくい緩効性であるため，畑等で使用しても雨水により， リンが環境中に流れ出すことはないため，富栄養化を引 き起こさない環境にやさしい肥料であり,また,アルカ り性を示すことから，日本に多く存在する火山灰性の酸 性土壌の中和にも役立つと考无られる。リン酸カルシウ ムには不純物として僅かにアルミニウムが含まれるが, アルミニウムはもともと土壤中には $5 \sim 12 \%$ 程度と比較 的多く存在することから肥料としての効果には影響がな いと考えられる。肥料取締法に基つくく普通肥料の重金属 についての規制はカドミウム，七素ともに大きく規制值
を下回って抢り，ニックル，クロム，鉛，水銀について は定量限界值以下であった。以上のことから肥料として 十分期待できるものであり実際にも良好な結果を得てい る5!。たた肥料以外の用途として飼料，リン鉱石代替品が 考えられる。一般的にりン酸カルシウムは飼料添加物と しても使用されている。農林水産省令で定められている 飼料添加物の中にはミネラルとして水酸化アルミニウム があること扔よび，アルミニウムを多く含んだリン酸バ ンド鉱も飼料として使用されている到ことからリン回収 物中に極わずかアルミニウムが含まれていても問題ない と考える。またりン酸カルシウムがリン鉱石代替品とし てリサイタルできれば，天然資源を消費せずにほとんど 全てのリン製品が製造可能となる。

\section{9 アルミニウム回収物について}

今回，焼却灰からアルミン酸ナトリウム水溶液として アルミニウムを回収した。アルミン酸ナトリウムは PAC (ポリ塩化アルミニウム)，硫酸バンドと同じようにアル ミニウム系凝集剤としての利用が考えられる。特に下水 処理，污泥処理施設において，回収したアルミン酸ナト リウムを使用することにより，排水中のりンを除去する ことが可能であるため閉鎖性水域の富栄責化防止に役立 つことができる。アルミニウムにより除去されたリンは リン酸アルミニウムとして存在するため，アルカリによ り溶出し，リンは回収され，リン除去に使用したアルミ ニウムは回収可能であることが確認できている7。また， アルミン酸ナトリウムは下式(6)により加水分解し, 水酸 化アルミニウムと水酸化ナトリウムが生成する。

$$
\mathrm{NaAlO}_{2}+\mathrm{H}_{2} \mathrm{O} \rightarrow \mathrm{Al}(\mathrm{OH})_{3}+\mathrm{NaOH}
$$

このため現在,アルミン酸ナトリウム溶液から工業原料 として利用しやすい水酸化アルミニウムとして回収する だけでなく再生された水酸化ナトリウムによるアルカリ 溶出時のさらなる薬品費の節隇に向けた実験も行い良好 な結舆を得ている8

\subsection{0 薬品コストについて}

筧却灰からリンとアルミニウムを回収するのに使用す る薬品は水酸化ナトリウムと水酸化カルシウムの 2 種類 であり，どちらも工業的に使用されていることから比較 的安価である。特に水酸化カルシウムの価格は水酸化ナ トリウムの約 1/2であり $1 \mathrm{~kg}$ あたり23〜28円程度と 安洒である。リンをリン酸カルシウムとして回収するこ とにより，水酸化ナトリウム使用量を60\%削減できたた め焼却圧 1 トンを処理するのに必要な試薬は水酸化ナ卜 りウム $88 \mathrm{~kg}$, 水酸化力ルシウム $130 \mathrm{~kg}$ である。また，そ の時得られるリン酸カルシウムは, 3.7 連続実験結果か ら $210 \mathrm{~kg}$ と計算される。現在検討中のアルミニウムの回 収方法浮用すれば，アルミン酸ナトリウムから水酸 化アルミニウムを生成する際にも水酸化ナトリウムが再 生されることから理論上は水酸化ナトリウムを使用せ ず，水酸化カルシウムたけでリン，アルミニウムが回収 可能である。実際には各工程間での損失が考えられるた め若千の水酸化ナトリウムを補充する必要があると考兄 られるが薬品費としては高価な水酸化ナトリウムを使用 しないことから大幅に下げることが可能と考える。

\section{4.まとめ}

焼却灭をアルカリ溶出させリン，アルミニウムを回収 


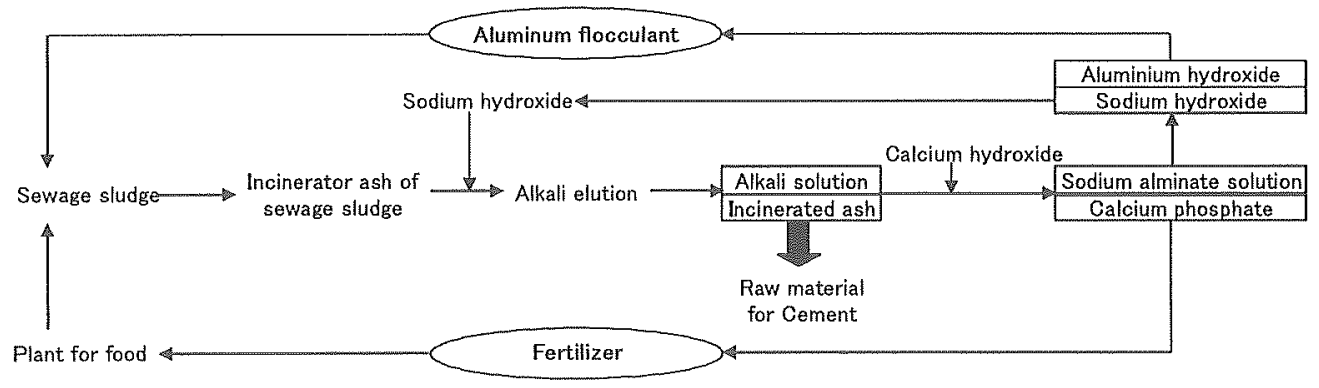

Fig. 6 Flow of recycle on $\mathrm{P}$ and $\mathrm{Al}$

する実験を行った結果，以下の知見が得られた。

1）アルカリ溶出液は $\mathrm{pH}$ が13以下では，カルシウム を加光たとき，リンだけでなくアルミニウムも沈殿して しまうことが確認できた。

2）アルカリ溶出液にカルシウム源として水酸化カル シウムを使用すれば $\mathrm{pH}$ 調整せずにアルミニウムの沈殿 を抑えることができ，リンとアルミニウムの分離が可能 となった。

3 ）カルシウム源として塩化カルシウムでなく水酸化 カルシウム使用することにより，沈降性，ろ過性の良 好なリン酸カルシウム定生成できた。

4) アルカリ溶出液中のリンに対して理論量の1.2倍 の水酸化カルシウムを水に眯濁させ添加した後，5時間 攪拌させることが最も効率的な条件であった。

5）リン回収後のろ液を雨利用することでアルカリ溶 出に必要な水酸化ナトリウムの約 $60 \%$ を削減することが 可能となった。

6）連続実験では平均リン回取率が97\%と良好な結果 が得られた。

7 ）回収したリン酸カルシウムはリンが $12 \%$ ，リン酸 に換算すると $36 \%$ も含まれており,100\%クエン酸溶性で あり肥料として十分期待できる。

8）回収したアルミン酸ナトリウム溶液はアルミニウ ム濃度が $17000 \mathrm{mg} \cdot l^{-1}$ での安定した回収ができ，回収物 は凝集㸞としての利用が考えられる。

9）計算上，焼却灰 1 トンを処理するのに水酸化ナト リウム $88 \mathrm{~kg}$ ，水酸化力ルシウム $130 \mathrm{~kg}$ を使用し，リン酸 カルシウムが $210 \mathrm{~kg}$ 得られる。

\section{5.おわりに}

下水污泥焼却灰から有害な重金属を溶出させることな くリンとアルミニウムを選択的に回収することが可能と なった。簡易なプロセスで安価な試薬のみを使用し，か つ資源として雨利用しやすい形態での回収が可能となっ たためより実用化に近づいた。Fig. 6 に示す循環型社会 に貢献できるリサイクルフローを構築し，環境保全と下 水道が有する資源の有効活用，資源循環の雨立を目指し ている。

(原稿受付 2003 年 7 月 8 日) （原稿受理２003年12月25日）

\section{参 考 文 献}

1 ）佐藤和明，伊藤久明，関根富明，平野裕司（1994）下水道施設 加の有用物回収技術に関する基儊調查，下水道新技術研究所年 報, p.86.

2）高橋泰弘，吉田佳子，洙田泰臣，兽根庸夫 (2001) 污泥燒却灰 に含ま机る有佂物の效率的な回収に関する研究, 下水道協会誌, $38(468), 181-192$.

3 ）村山勝男（1992）排水中のリン除去とリサイクリング，資源環 境対策, 28(12)，1099 1106.

4) 松野清一，堀越孝和 (1980) 水酸アパ夕イトの生成領域，石膏 と石灰, $165(9), 9-16$.

5 ）高橋泰弘, 吉田佳子, 宇城碩弥 (2002) 焼却灰からりン酸力ル シウムとしてのリン回収と肥料効果, 第39回下水道研究発表講演 集, pp.37-39.

6）金澤孝文（1985）無機リン化学，講談社，p. 9 .

7) 原文俊, 高橋泰弘, 宇城碩弥 (2003) 污泥処理返流水のリン除 去と効率的なリン回取堂目的とした污泥処理方法の検討, 第40回 下水道研究発表会, pp.985-987.

8 ) 高橋泰弘, 原文俊, 宇城碩弥 (2003) 燒却灰からリン酸カルシ ウムとしてのリン回収とアルミニウムの回収, 第40回下水道研究 発表会, pp.415-417. 